\title{
What are the determining factors in the capital structure decisions of small and medium-sized firms in Cabinda, Angola?*,**
}

\author{
João Lussuamo ${ }^{1,2}$ \\ (D) https://orcid.org/0000-0001-8113-9394 \\ Email: jlussuamo1@hotmail.com \\ Zélia Serrasqueiro ${ }^{1}$
(D) https://orcid.org/0000-0003-1761-5426
Email: zelia@ubi.pt \\ ${ }^{1}$ Universidade da Beira Interior, Departamento de Gestão e Economia, Covilhã, Portugal \\ ${ }^{2}$ Universidade Onze de Novembro, Faculdade de Economia, Cabinda, Angola
}

Received on 10.31.2019 - Desk acceptance on 11.14.2019 - 3rd version approved on 01.07.2021 - Ahead of print on 06.25.2021

Editor-in-Chief: Fábio Frezatti

Associate Editor: Fernanda Finotti Cordeiro

\begin{abstract}
The objective of this study was to analyze the determining factors that explain the capital structure decisions of small and medium-sized enterprises (SMEs) in the province of Cabinda, Angola. In this study, debt maturity was also analyzed and, therefore, total indebtedness was broken down into short, medium, and long-term debt ratios. This study is motivated the poor number of studies on the determinants of the capital structure of SMEs in developing countries, more specifically in Cabinda, Angola. This research is relevant for Corporate Finance, particularly regarding the capital structure of SMEs located in a developing country like Angola. Also, it corroborates previous studies on the applicability of the principles of the pecking-order theory to SMEs in developed countries. This research present contributions to Corporate Finance, as it identifies the determinants of the capital structure of SMEs in a developing country - considering the debt maturity -, through the analysis of total debt ratios-, short-, medium- and long-term debt. Based on a sample of 73 SMEs for the period between 2011 and 2016, we used panel data models (pooled OLS, fixed and random effects). The results of this study show that tangibility, age, liquidity, and non-debt tax shield are determining factors in the decisions of the capital structure of SMEs in the province of Cabinda, Angola. Furthermore, they suggest that these firms follow the principles of pecking-order theory in capital structure decisions. The research contributes to increase studies in Corporate Finance, particularly concerning the determinants of the capital structure of SMEs located in a developing country.
\end{abstract}

Keywords: Angola - Cabinda, capital structure decisions, panel data models, SMEs.

Correspondence address

João Lussuamo

Universidade 11 de Novembro, Departamento de Economia

Rua Comendador Henrique Serrano

Cabinda - Angola

* This work was presented at the event XXX Jornada Luso-Espanhola de Gestão Científica, Bragança, Portugal, February 2020.

** Zélia Serrasqueiro gratefully acknowledges the financial support of the research unit Center for Advanced Studies in Management and Economics of the University of Beira Interior (CEFAGE-UBI), promoted by FCT - Fundação para a Ciência e a Tecnologia, project UIDB/04007/2020. 


\section{INTRODUCTION}

The studies on the capital structure started with Durand (1952) and, later, Modigliani and Miller (1958, 1963). Based on these pillars, an increasing number of studies have been conducted to identify the main determinants of firms' financing decisions (Buvanendra, Sridharan, \& Thiyagarajan, 2017).

Most small and medium-sized enterprises (SMEs) are absent from the stock market, as they do not meet the requirements, and thus face difficulties in accessing external financing, especially long-term debt (Sardo \& Serrasqueiro, 2017). Therefore, these firms depend on retained earnings and short-term debt to finance their current activities and investments (Sardo \& Serrasqueiro, 2017). SMEs are more exposed to asymmetric information problems than large firms, due to the lack of financial information disclosure, and the ownership and management being concentrated in a small number of individuals (Rao \& Kumar, 2018). This situation implies that creditors will require guarantees from SMEs in return for the granting of medium and long-term debt (Michaelas, Chittenden, \& Poutziouris, 1999; Rao \& Kumar, 2018). Consequently, these firms are dependent on short-term debt as a source of external financing (Heyman, Deloof, \& Ooghe, 2008; Scherr \& Hulburt, 2001).

SMEs seem to follow the assumptions of the pecking order theory, particularly a modified version of this theory, as these firms do not issue shares to finance themselves, since they are absent from the stock market, and appear to have access to a limited number of external sources of financing, depending heavily on short-term debt (Holmes $\&$ Kent, 1991). However, this dependence on third-party capital as a source of external financing obliges SMEs to control their levels of indebtedness, as high levels of indebtedness increase the financial risk and the probability of bankruptcy of the firm. Consequently, there is a reason for these firms to consider the assumptions of the tradeoff theory in their capital structure decisions, comparing the tax benefits with the bankruptcy costs associated with the debt.

SMEs have an important role in the economic growth and development of countries, especially in developing countries. Their contributions include poverty reduction, increased job opportunities, competitiveness, among others (Erdogan, 2018). Despite the important role they play in the economic scenario, SMEs have faced difficulties in accessing finance, with a lack of investment opportunities worldwide. This particularly affects SMEs in Africa, namely SMEs located in Cabinda, Angola (Fowowe, 2017; Wong, Holmes, \& Schaper, 2018; Zhao \& Jones-Evans, 2016). To the best of our knowledge, most studies on the determinants of capital structure decisions are centered on contexts from continents other than Africa, while few studies focus on the African continent, as is the case in Angola.

This paper aims to analyze the determinants of the capital structure decisions of non-financial SMEs located in the Sub-Saharan Africa region, specifically in the province of Cabinda, Angola, for the period between 2011-2016, by applying panel data models. Our goal is to contribute to the literature by analyzing a set of SMEs in a geographic context that has been poorly investigated so far, and considering the economic development asymmetries, to investigate potential differences between the various municipalities from the province of Cabinda, Angola, and its capital. Thus, we analyze the debt variable as a proxy for the capital structure. Following the work of Bevan and Danbolt (2002), who concluded that the relationships between the determinants and the capital structure of SMEs can depend on the debt maturity, this study analyzes the impact of the determinants of the capital structure on total indebtedness, short-term indebtedness, and medium and long-term indebtedness.

The results obtained in this research suggest that the capital structure decisions of SMEs in Cabinda are explained by the following determining factors: firm age, tangibility, liquidity, and non-debt tax shield. However, the location variable, comparing the SMEs from the capital and the other municipalities, was not identified as a determining factor in capital structure decisions. The results suggest that SMEs in the province of Cabinda closely follow the principles of the pecking order theory.

Besides this section, this paper also presents a brief literature review on determining factors (specific and location factors) in capital structure decisions and the research hypotheses; methodology; empirical results; conclusion, limitations, and future research perspectives. 


\section{THEORETICAL FRAMEWORK AND RESEARCH HYPOTHESES}

\subsection{Capital Structure Theories}

Since the seminal work of Modigliani and Miller (1958), the theories of capital structure decisions have shown substantial progress. Some theories have gained prominence, namely the trade-off theory (Kraus \& Litzenberger, 1973), the pecking order theory (Myers, 1984; Myers \& Majluf, 1984), the agency theory (Jensen, 1986; Jensen \& Meckling, 1976), and the market timing hypothesis (Baker \& Wurgler, 2002). For SMEs, trade-off theory and pecking order theory seems to present higher relevance, according to empirical study results.

According to Ezirim, Ezirim, and Momodu (2017), in a classic vision, the trade-off theory was initially developed in 1973 by Kraus and Litzenberger, with the argument that firms choose their optimal capital structure when assessing benefits and costs associated with debt. Several studies support this argument (Benkraiem \& Gurau, 2013; Li \& Islam, 2019) that defend the trade-off theory, emphasizing that the capital structure reaches the optimum when the tax benefits equal the costs of bankruptcy, that is, the firm's level of indebtedness is increased to the extent that the marginal tax benefits associated with this increase outweigh the firm's bankruptcy costs (Li \& Islam, 2019).

In the framework of the pecking order theory of Myers and Majluf (1984) and Myers (1984), the information asymmetry is reflected in the cost of external sources of financing. Thus, the minimization of financing costs consists of the priority use of the profits accumulated by the firm to finance its current needs and its investment projects.

The insufficiency of profits implies the use of external financing that, hierarchically, will fall on indebtedness, and then on the issuance of new shares (Burgstaller \& Wagner, 2015). The assumptions of the pecking order theory may apply to SMEs. Considering that most SMEs are out of the stock market, they depend on debt as an external source of financing. Holmes and Kent (1991) propose a modified version of this theory in the context of small and medium-sized firms, given that these firms depend almost exclusively on indebtedness as an external source, as they rarely have access to the stock market, and, therefore, do not resort to the issue of shares.

\subsection{Determining Factors of the Capital Structure}

The capital structure refers to equity and third-party capital used by the firm to finance its investments. The literature on capital structure decisions has focused on the analysis of the effects of determinants on indebtedness, considering it as a proxy for the capital structure. Most studies focus on total indebtedness as a proxy for the capital structure, however, Bevan and Danbolt (2000) conclude that the determinants of indebtedness strongly depend on the component of indebtedness under analysis and that there are significant differences between the determinants of short-term indebtedness and those of long-term indebtedness. In line with several studies (Bevan \& Danbolt, 2002; Lisboa, 2017; Mac an Bhaird \& Lucey, 2010; Maes et al., 2019; Öhman \& Yazdanfar, 2017; Yazdanfar \& Öhman, 2016), in this research, we analyze the determinants of total indebtedness, long-term indebtedness, and short-term indebtedness.

Previous studies on capital structure decisions of SMEs have considered specific factors of the firm (Dwyer \& Kotey, 2015; Matias \& Serrasqueiro, 2017; Palacín-Sánchez, Ramírez-Herrera \& di Pietro, 2013; Sardo \& Serrasqueiro, 2017), factors related to the firm's managers (Dasilas \& Papasyriopoulos, 2015; Lee, Sameen, \& Cowling, 2015; Matemilola, Bany-Ariffin, Azman-Saini, \& Nassir, 2018), and also macroeconomic factors (Adair \& Adaskou, 2015; Matias, Baptista, \& Salsa, 2015; Mc Namara, Murro, \& O’Donohoe, 2017).

In this study, we considered the following specific factors of the firm: size, age, tangibility of the asset, profitability, growth opportunities, liquidity, and nondebt tax shield, and also included the variable location of the firm, to take into account the possible effect of the economic asymmetries that exist between the capital of Cabinda and the province's country towns.

\subsubsection{Size or dimension of the firm}

The size of the firm is considered in several studies (Bhaird \& Lucey, 2014; Hendrawan, 2012) as one of the most relevant factors for access to debt, especially regarding access to long-term debt. Fama and French (2002) and Haro-de-rosario, Caba-Pérez, and Cazorla-papis (2015) point out that the size of the firm is associated with its level of indebtedness. Although there is no consensus on the 
type of relationship, a negative relationship was identified between the size of SMEs and the level of short-term debt (Ohman \& Yazdanfar, 2017; Serrasqueiro \& Nunes, 2012) and a positive relationship between the dimension and long-term debt (Serrasqueiro \& Nunes, 2012). On the other hand, some studies have found no evidence that the size of the firm is related to the firm's level of indebtedness (Peñaloza \& Figueiredo, 2011; Santos, Ribeiro, Silva, \& Melo, 2016).

According to Hendrawan (2012), in large firms and SMEs, the dimension is positively related to the level of indebtedness. However, Haro-de-rosario et al. (2015) highlight that this relationship is conflicting in the context of SMEs since some empirical studies have found a positive relationship while others have found a negative one. Vatavu (2012), based on the trade-off theory, mentions the existence of a positive relationship between the size of the firm and the level of indebtedness.

Al-Najjar and Al-Najjar (2017) and Ohman and Yazdanfar (2017) argue that large firms, generally, are most diversified, face less problems of information asymmetry, less moral risk and risk of bankruptcy, less financial difficulties, and may have access to a large proportion of long-term debt, while SMEs tend to use short-term debt as a substitute for long-term debt to minimize the impact of information asymmetry problems. Therefore, based on the previous evidence, we present the following research hypotheses:

$H_{1 a}:$ There is a positive relationship between the size of the firm and the short-term debt of SMEs;

$H_{1 b}$ : There is a positive relationship between the size of the firm and the medium and long-term debt of SMEs;

$H_{1 c}:$ There is a positive relationship between the size of the firm and the total indebtedness of SMEs.

\subsubsection{Firm age}

The age of a firm gives it a reputation, notoriety, credibility, and a level of tangible assets that can influence the ability and conditions of access to third-party capital (Serrasqueiro \& Nunes, 2012; Vieira \& Novo, 2010). The effect of the firm's age variable on indebtedness is seen with some controversy in the literature (Burgstaller \& Wagner, 2015; Vieira \& Novo, 2010).

Some studies (Burgstaller \& Wagner, 2015; Dwyer \& Kotey, 2015; Haro-de-rosario et al., 2015; Serrasqueiro $\&$ Nunes, 2012) state that older firms are seen as already stabilized firms and, consequently, have a greater possibility to choose between short or long-term debt, as these firms obtain a large part of external resources with longer repayment terms to finance their growth, in comparison with firms whose age is younger, as older firms are exposed to a relatively minor degree of information asymmetry and bankruptcy risk.

The pecking order theory suggests that younger firms tend to rely more on external financing than older firms. Based on this theory, Ohman and Yazdanfar (2017) state that older firms resort less to debt, assuming that they have accumulated profits that can be used to finance their activities. Based on previous studies, we present the following research hypotheses:

$H_{2 a}$ : There is a negative relationship between SMEs' age and shortterm debt.

$H_{2 b}$ : There is a negative relationship between age and the medium and long-term indebtedness of SMEs.

$H_{2 c}$ : There is a negative relationship between age and the total indebtedness of SMEs.

\subsubsection{Asset tangibility}

Tangible assets represent an important element for obtaining capital from third parties, that is, the higher the level of tangible assets held by the firm, the greater the likelihood that it will be financed with financial resources from third parties and at lower costs. Several authors state that, on the one hand, a firm with a high amount of tangible assets may be able to increase its liquidation value, on the other hand, these assets can serve as collateral and, therefore, guarantee the repayment of the debt, thus minimizing the risk of creditors (Benkraiem \& Gurau, 2013).

Cassar and Holmes (2003) and Ohman and Yazdanfar (2017), on the capital structure of SMEs, concluded that the tangibility of a firm's assets has a positive relationship with long-term indebtedness and total indebtedness. Therefore, the greater the number of tangible assets of a firm, the greater the probability that the firm will resort to long-term debt through financial institutions since they are firms that are generally more diversified and with more stable cash flows. (De Jong, Kabir, \& Nguyen, 2008; Ohman \& Yazdanfar, 2017). Given the above, we present the following research hypotheses:

$H_{3 a}:$ There is a negative relationship between tangible assets and the short-term debt of SMEs.

$H_{3 b}$ : There is a positive relationship between tangible assets and the medium and long-term debt of SMEs.

$H_{3 c}:$ There is a positive relationship between tangible assets and the total indebtedness of SMEs. 


\subsubsection{Profitability}

Profitability is also considered as one of the determining factors in the firms' capital structure decisions. Studies on its relationship with the level of indebtedness present contradictory results. While some empirical evidence verified a positive relationship (Nunkoo \& Boateng, 2010), others found a negative relationship (Degryse, de Goeij, \& Kappert, 2012; Fama \& French, 2002; Matias \& Serrasqueiro, 2017; Mc Namara et al., 2017).

According to the pecking order theory, the relationship between profitability and the level of indebtedness is negative as firms follow a hierarchy in the choice of financing sources in their capital structure decisions, due to information asymmetry, privileging the use of internal funds to external financing (Benkraiem \& Gurau, 2013; Myers, 1984; Myers \& Majluf, 1984; Proença, Laureano, \& Laureano, 2014; Öhman \& Yazdanfar, 2017). Hence Öhman and Yazdanfar (2017) argue that firms with an acceptable degree of profitability tend to reduce agency costs related to debt and, consequently, to reduce the debt ratio. Considering these authors, we present the following research hypotheses:

$H_{4 a}:$ There is a negative relationship between profitability and shortterm debt for SMEs.

$H_{4 b}$ : There is a negative relationship between profitability and the medium and long-term indebtedness of SMEs.

$H_{4 i}$ : There is a negative relationship between profitability and the total indebtedness of SMEs.

\subsubsection{Growth opportunities}

Growth opportunities are considered by several authors as one of the determining factors of the capital structure (Dasilas \& Papasyriopoulos, 2015; Nunkoo \& Boateng, 2010). Within the framework of the agency's theory, Jensen and Meckling (1976) argue that firms choose debt to finance their investment opportunities.

The trade-off theory suggests that growth opportunities are negatively related to the firm's indebtedness, as firms with greater growth possibilities tend to incur higher bankruptcy and agency costs. The pecking order theory suggests a negative relationship between those two variables, given that investment opportunities are associated with risk and intangible assets, hindering access to indebtedness. However, if the firm does not have sufficient internal financing to implement its investment opportunities, it will be obliged to resort to debt (Dasilas \& Papasyriopoulos, 2015; Degryse et al., 2012; Proença et al., 2014). Therefore, we present the following research hypotheses:
$H_{5 a}$ : There is a positive relationship between growth opportunities and short-term debt for SMEs.

$H_{5 b}$ : There is a positive relationship between growth opportunities and the medium and long-term indebtedness of SMEs.

$H_{5 c}:$ There is a positive relationship between growth opportunities and the total indebtedness of SMEs.

\subsubsection{Liquidity}

Liquidity measures the firm's ability to meet its commitments on dates agreed with creditors (Kontuš \& Mihanović, 2019). A higher level of current assets provides a higher level of liquidity; therefore, it reduces the firm's default risk. According to Kontuš and Mihanović (2019), there is a trade-off between liquidity and profitability, so firms tend to avoid an excessive level of liquidity.

The management of the liquidity level is particularly important in the context of SMEs as they are firms dependent on short-term debt and need to pay their debts on the dates agreed with creditors, otherwise, they will not be able to renegotiate credit on favorable terms (Kontuš \& Mihanović, 2019). Higher levels of liquidity have a negative impact on indebtedness when the firm has a higher level of funds to finance its investment (Lisbon, 2017; Proença et al., 2014). Proença et al. (2014) and Lisboa (2017) concluded that the relationship between liquidity and indebtedness depends on the maturity of the debt, identifying a positive relationship between liquidity and long-term indebtedness, and a negative relationship between liquidity and short-term indebtedness. Vieira and Novo (2010) analyzed 51 Portuguese SMEs in the period between 2000 and 2005, while Proença et al. (2014) analyzed a sample of 12,857 Portuguese SMEs for the period 2007-2010. Those authors concluded that liquidity, in addition to profitability and asset structure, is one of the most important determining factors in explaining capital structure decisions.

Burgstaller and Wagner (2015) argue that the trade-off theory suggests a positive relationship between liquidity and the debt ratio. On the other hand, Öhman and Yazdanfar (2017) conclude, based on the pecking order theory, that liquidity is negatively related to debt in SMEs. An increase in financial resources generated by retained earnings and available in terms of liquidity allows firms to be less dependent on third-party capital (De Jong et al., 2011; Öhman \& Yazdanfar, 2017).

According to several authors (Kontuš \& Mihanović, 2019; Lisbon, 2017; Öhman \& Yazdanfar, 2017), firms with a stable liquidity situation prefer to resort to domestic financing. The empirical evidence obtained by these authors indicates a negative and statistically 
significant relationship between liquidity and the level of indebtedness. Based on these approaches, we present the following research hypotheses:

$H_{6 a}:$ There is a negative relationship between liquidity and shortterm debt of SMEs.

$H_{6 b}$ : There is a negative relationship between liquidity and the medium and long-term debt of SMEs.

$H_{6 c}:$ There is a negative relationship between liquidity and the total indebtedness of SMEs.

\subsubsection{Non-debt tax shield}

Interest on debt can reduce the amount of tax on company profits (Vatavu, 2012). Based on the trade-off theory, Öhman and Yazdanfar (2017) predict a negative relationship between non-debt tax shield and the level of indebtedness of SMEs, corroborating the results of previous studies (Frank \& Goyal, 2003).

Some studies have identified a positive relationship between non-debt tax shield and the level of indebtedness (Jiraporn \& Gleason, 2007). In turn, Degryse et al. (2012) identified a positive relationship between short-term debt, but a negative relationship between long-term debt and non-debt tax shield. According to Ahmad and EtudaiyeMuhtar (2017), non-debt tax shield have a significant effect on the capital structure of SMEs, being positive in relation to short-term indebtedness and negative in relation to long-term indebtedness. Based on the previous arguments, we present the following research hypotheses:

$H_{7 a}:$ There is a positive relationship between non-debt tax shield and the short-term debt of SMEs.

$H_{7 b}$ : There is a negative relationship between non-debt tax shield and medium and long-term indebtedness of SMEs.

$H_{7 c}$ : There is a positive relationship between non-debt tax shield and total SME indebtedness.

\subsubsection{Geographic location}

Some studies have analyzed whether geographic location can influence the firm's capital structure (Hendrawan, 2012; Russo \& Rossi, 2001).

For European SMEs, Hall, Hutchinson and Michaelas (2004) concluded that there is a relationship between geographic location and capital structure decisions. Harode-rosario et al. (2015) found statistically significant evidence of the influence of location on the capital structure of Spanish firms. In Italy, characterized by strong differences, Russo and Rossi (2001) analyzed 1,700 firms in the period 1989-1995, and concluded that firms in industrial parks have less difficulty in accessing bank financing than firms that are outside them, that is, there is a relationship between the firm's location and its level of indebtedness.

In the same vein, Hendrawan (2012), in his study of SMEs, identified a positive and statistically significant relationship between the location of SMEs in industrial/ business parks and their obtaining of bank loans, compared to firms located outside the industrial park, achieving similar results to Russo and Rossi (2001).

The location variable is implemented as a dummy variable in this research, with a value of 1 if the firm is in the province's capital (Cabinda) and 0 , otherwise, that is, the province's country towns (Cacongo, Buco-Zau, and Belize). With the support of previous studies, we present the following research hypotheses:

\footnotetext{
$H_{8 a}$ : There is a relationship between the location and the level of short-term debt of SMEs.

$H_{s b}$ : There is a relationship between the location and the level of medium and long-term indebtedness of SMEs.

$H_{8 c}:$ There is a relationship between the location and the level of the total indebtedness of SMEs.
}

\section{METHODOLOGY}

\subsection{Data Source, Sample, and Variables}

There are practically no databases on SMEs for the development of scientific research, in Angola in general and in the province of Cabinda in particular. For this reason, we use financial data, more specifically, the financial statements provided by the firms under study, requesting them from the authority of the third tax region, known as the General Tax Administration (AGT). The
SMEs considered in the present study are not part of the financial sector and satisfy the conditions established in Law No. 30/11, of September 13, that is, they have a number of workers not less than 10 and not more than 200 and a turnover between 250 thousand dollars and 10 million dollars, equivalent in Kwanzas (the national currency). The sample obtained is composed of 73 SMEs and the data were collected for the period between 2011 2016, totaling 438 observations. 
Table 1 shows the sample composition by sector of activity. In this study, and following previous studies (Bevan \& Danbolt, 2002; Proença et al., 2014; Lisbon, 2017; Öhman \& Yazdanfar, 2017; Vieira \& Novo, 2010) that, in the context of SMEs, evidence the relevance of analyzing both total indebtedness, short-term indebtedness and long-term indebtedness, we considered as dependent variables: short-term indebtedness (EndCP), medium and long-term indebtedness (EndMLP) and total indebtedness (EndT). The determination of these variables was based on several authors (Matias \& Serrasqueiro, 2017; Öhman \& Yazdanfar, 2017), and defined as the ratio between debt levels (short, medium, and long term and total) and total assets.

Table 1

SME Sample distribution in the period 2011-2016

\begin{tabular}{cccc}
\hline Activity Sector & No. of PMEs & Percentage & No. of Observations \\
\hline Hospitality & 6 & 8 & 36 \\
\hline Commerce & 24 & 33 & 144 \\
\hline Construction & 11 & 15 & 66 \\
\hline Industry & 8 & 11 & 48 \\
\hline Service delivery & 11 & 15 & 66 \\
\hline Education (private) & 6 & 8 & 36 \\
\hline Transport & 2 & 3 & 12 \\
\hline Others & 5 & 7 & $\mathbf{1 0 0}$ \\
\hline Total & $\mathbf{7 3}$ & $\mathbf{4 3 8}$
\end{tabular}

Source: Prepared by the authors

Following several studies, we considered as independent variables: firm size (DIM) based on (Yildirim, Masih, \& Bacha, 2018); firm age (IDADE), determined based on several authors (Matias \& Serrasqueiro, 2017; Yazdanfar \& Öhman, 2016); tangibility of the asset (TANG) measured following the authors (Benkraiem \& Gurau, 2013; Matias \& Serrasqueiro, 2017); profitability (RENT), calculated based on several studies (Mc Namara et al., 2017); growth opportunities (OpCr), following the authors Adair and Adaskou (2015) and Ahmad and Etudaiye-Muhtar (2017); liquidity (LIQ), based on several authors (Proença et al., 2014; Takele \& Beshir, 2017); non-debt tax shield (BFEx), according to several authors (Ahmad \& Etudaiye-Muhtar, 2017; Michaelas et al., 1999) and firm location (LOC), as a dummy variable, following the authors Haro-de-rosario et al. (2015) and Russo and Rossi (2001); assuming a value of 1 if the firm is located in the capital of Cabinda and 0, otherwise. Table 2 shows how we determined all the variables in this research.

Table 2

Determination of study variables

\begin{tabular}{|c|c|c|}
\hline Variables & Calculation & Authors \\
\hline \multicolumn{3}{|l|}{ Dependent } \\
\hline $\begin{array}{l}\text { Short-term indebtedness } \\
\quad(\text { EndCP })\end{array}$ & $\frac{\text { Short }- \text { term borrowed capital }}{\text { Total assets }}$ & $\begin{array}{l}\text { Cassar and Holmes (2003); } \\
\text { Mateeva, Poutziouris, and Ivanov (2013); Rao et al. (2019) }\end{array}$ \\
\hline $\begin{array}{l}\text { Medium and long-term } \\
\text { indebtedness (EndMLP) }\end{array}$ & $\frac{\text { Long }- \text { term borrowed capital }}{\text { Total assets }}$ & $\begin{array}{c}\text { Cassar and Holmes (2003); } \\
\text { Mateeva et al. (2013); Rao, Kumar and Madhavan (2019) }\end{array}$ \\
\hline Total indebtedness (EndT) & $\frac{\text { Total borrowed capital }}{\text { Total assets }}$ & $\begin{array}{l}\text { Cassar and Holmes (2003); } \\
\text { Mateeva et al. (2013); Rao et al. (2019) }\end{array}$ \\
\hline \multicolumn{3}{|l|}{ Independent } \\
\hline Tangibilidade (TANG) & $\frac{\text { Tangible assets }}{\text { Total assets }}$ & $\begin{array}{l}\text { Benkraiem and Gurau (2013); Mateeva et al. (2013); } \\
\text { Matias and Serrasqueiro (2017); Rao et al. (2019) }\end{array}$ \\
\hline
\end{tabular}


Table 2

Cont.

\begin{tabular}{ccc}
\hline Variables & Calculation & Authors \\
\hline Growth opporunities (OpCr) & $\begin{array}{c}\text { Intangible assets } \\
\text { Total assets }\end{array}$ & $\begin{array}{c}\text { Adair and Adaskou (2015); Ahmad and Etudaiye-Muhtar } \\
\text { (2017); Rao et al. (2019) }\end{array}$ \\
\hline Profitability (RENT) & $\begin{array}{c}\text { Operational results } \\
\text { Total assets }\end{array}$ & Bhaduri (2002); Mc Namara et al. (2017); Rao et al. (2019) \\
\hline Dimension (DIM) & Sales log & Chakraborty (2010); Yildirim et al. (2018); Rao et al. (2019) \\
\hline Age (IDADE) & $\frac{\text { Current assets }}{\text { Current liabilities }}$ & $\begin{array}{c}\text { Bhaird and Lucey (2010); Matias and Serrasqueiro (2017); } \\
\text { Yazdanfar and Öhman, (2017); Rao et al. (2019) }\end{array}$ \\
\hline Liquidity (LIQ) & $\begin{array}{c}\text { Depreciation } \\
\text { Total assets }\end{array}$ & $\begin{array}{c}\text { Proença et al., (2014); Lisboa (2017);Takele and Beshir } \\
\text { (2017); Rao et al. (2019) }\end{array}$ \\
\hline Non-debt Tax Shield (BFEx) & Dummy (being: 1 capital and 0 otherwise \\
i.e., province's country towns) & $\begin{array}{c}\text { Russo and Rossi (2001); Haro-de-rosario et al. (2015); Rao } \\
\text { et al. (2019) }\end{array}$ \\
\hline
\end{tabular}

Source: Prepared by the authors

\subsection{Econometric Model}

To estimate the relationships between the levels of indebtedness and the determinants selected in the present study, we applied the panel data models, based on three equations, considering the three levels of indebtedness that represent the dependent variables. Therefore, the models are as follows:

$$
E_{n d}=\beta_{0}+\beta_{1} T A N G_{i t}+\beta_{2} O p C r_{i t}+\beta_{3} R E N T_{i t}+\beta_{4} D I M_{i t}+\beta_{5} I D A D E_{i t}+\beta_{6} L I Q_{i t}+\beta_{7} B F E x_{i t}+\beta_{8} L O C_{i}+u_{i}
$$

where $E n d_{i t}$ represents the dependent variable indebtedness (the equation will be estimated in three distinct phases, according to the dependent variable: total indebtedness; medium and long-term indebtedness; short-term indebtedness) of firm $i$ at time $t, \beta_{p} j=0,1, \ldots, 8$, are the model parameters; $u_{i t}$ is the error term for firm $i$ at time $t$; and the rest are the determining factors of the capital structure, mentioned in Table 2.
The methodology used in this study on the capital structure has been applied in several studies in different contexts - such as, for example, Palacín-Sánchez et al. (2013), Matias and Serrasqueiro (2017), and Li and Islam (2019) - to test the determinants of the firm's capital structure. The model was subjected to several tests for its validation, such as tests for variance inflation factors (VIF), heteroscedasticity, Breusch-Pagan Langrange Multiplier (LM), and autocorrelation.

\section{RESULTS AND DISCUSSION}

In this section, we present the results obtained by estimating the three models. For the first model, the dependent variable is short-term debt $\left(\right.$ EndCP $\left._{i t}\right)$, and for the second and third models, the dependent variables are medium and long-term debt $\left(\right.$ EndMLP $\left._{\text {it }}\right)$ and total $\left(\right.$ EndT $\left._{\text {it }}\right)$, respectively, based on the application of an OLS regression and static panel data models of fixed and random effects.

Table 3 presents the descriptive statistics of the dependent and independent variables. We can see that the SMEs under analysis have, above all, short-term debt, with very low levels of medium and long-term debt. Thus, the average level of total debt is close to the average level of short-term debt. These results show the need to analyze capital structure decisions, analyzing in addition to the total debt ratio, short-term and medium and long-term debt ratios. In average terms, the total debt ratio reflects the level of short-term debt of SMEs in Cabinda. 
Table 3

Descriptive statistics

\begin{tabular}{|c|c|c|c|c|c|}
\hline Variables & Observations & Mean & Standard deviation & Minimum & Maximum \\
\hline EndCP $_{\text {it }}$ & 438 & 0.20318 & 0.29618 & 0 & 0.99401 \\
\hline EndMLP $_{\text {it }}$ & 438 & 0.07040 & 0.16144 & 0 & 0.95457 \\
\hline EndT $_{\text {it }}$ & 438 & 0.27358 & 0.32621 & 0 & 0.99667 \\
\hline Tang $_{\text {it }}$ & 438 & 0.61184 & 0.28128 & 0.00825 & 0.98891 \\
\hline $\mathrm{OpCr}_{\mathrm{it}}$ & 438 & 0.01607 & 0.04720 & 0 & 0.28834 \\
\hline Rent $_{\text {it }}$ & 438 & 0.25462 & 0.29730 & -0.06783 & 1.44446 \\
\hline $\operatorname{Dim}_{i t}$ & 438 & 17.78410 & 1.54972 & 13.04399 & 21.15483 \\
\hline Idade $_{i t}$ & 438 & 2.263642 & 0.567375 & 0 & 3.218876 \\
\hline $\operatorname{Liq}_{i t}$ & 413 & 3.02699 & 3.10336 & 0.05795 & 9.95038 \\
\hline BFEx $_{i t}$ & 438 & 0.06519 & 0.07837 & 0.00003 & 0.39858 \\
\hline
\end{tabular}

Source: Prepared by the authors

Table 4 shows the correlation matrix of the studied variables. Considering these values, we can conclude that there are no multicollinearity issues between the dependent and independent variables.

\section{Table 4}

Correlation matrix

\begin{tabular}{|c|c|c|c|c|c|c|c|c|c|c|c|}
\hline & 1 & 2 & 3 & 4 & 5 & 6 & 7 & 8 & 9 & 10 & 11 \\
\hline 1 & 1.000 & & & & & & & & & & \\
\hline 2 & 0.010 & 1.000 & & & & & & & & & \\
\hline 3 & $0.893^{* * *}$ & $0.404^{* * *}$ & 1.000 & & & & & & & & \\
\hline 4 & $-0.245^{* * *}$ & -0.037 & $-0.238^{* * *}$ & 1.000 & & & & & & & \\
\hline 5 & $0.180^{* * *}$ & -0.071 & $0.136^{* * *}$ & $-0.101 * *$ & 1.000 & & & & & & \\
\hline 6 & $-0.164 * * *$ & 0.075 & $-0.095^{* *}$ & 0.070 & -0.075 & 1.000 & & & & & \\
\hline 7 & $-0.225^{* * *}$ & $0.132^{* * *}$ & $-0.121^{* *}$ & $0.096^{* *}$ & $-0.413 * * *$ & $0.311^{* * *}$ & 1.000 & & & & \\
\hline 8 & $-0.259 * * *$ & 0.012 & $-0.222 * * *$ & 0.016 & $-0.220^{* * *}$ & $0.135^{* *}$ & $0.407^{* * *}$ & 1.000 & & & \\
\hline 9 & $-0.473 * * *$ & -0.031 & $-0.403^{* * *}$ & $-0.262^{* * *}$ & $-0.241^{* * *}$ & $0.286^{* * *}$ & $0.326^{* * *}$ & $0.210^{* * *}$ & 1.000 & & \\
\hline 10 & $0.189 * * *$ & $0.230^{* * *}$ & $0.284^{* * *}$ & $0.196^{* * *}$ & -0.028 & 0.021 & -0.043 & $-0.120^{* *}$ & $-0.361^{* * *}$ & 1.000 & \\
\hline 11 & $-0.143^{* * *}$ & 0.036 & $-0.122^{* *}$ & $-0.185^{* * *}$ & 0.033 & $0.132^{* * *}$ & $0.295^{* * *}$ & $0.375^{* * *}$ & $0.234^{* * *}$ & $-0.215^{* * *}$ & 1.000 \\
\hline
\end{tabular}

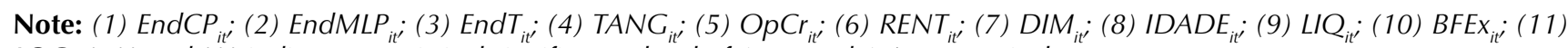
$\operatorname{LOC}_{i}{ }^{*},{ }^{* *}$ and ${ }^{* * *}$ indicate a statistical significance level of 10,5 and $1 \%$, respectively.

Source: Prepared by the authors.

The results of the estimates are presented in tables 5,6 , and 7 , for the three short-term debt, medium, and long-term debt, and total debt indicators, respectively. The values of the determination coefficient $\left(\mathrm{R}^{2}\right)$ of the models can be considered as relevant, that is, above $50 \%$, thus concluding that the explanatory variables have an impact on the dependent variable. 
Table 5

Determinants of short-term debt (EndCP)

\begin{tabular}{|c|c|c|c|}
\hline Independent variables & $\stackrel{(1)}{\text { Pooled OLS }}$ & $\begin{array}{c}(2) \\
\text { Fixed effects }\end{array}$ & $\begin{array}{c}\text { (3) } \\
\text { Random effects }\end{array}$ \\
\hline TANG $_{\text {it }}$ & $\begin{array}{c}-0.389 * * * \\
(-9.57)\end{array}$ & $\begin{array}{c}-455^{* * *} \\
(-5.22)\end{array}$ & $\begin{array}{c}-0.427^{* * *} \\
(-7.32)\end{array}$ \\
\hline $\mathrm{OpCr}_{\text {it }}$ & $\begin{array}{l}0.120 \\
(0.43)\end{array}$ & $\begin{array}{l}-0.866 \\
(-1.46)\end{array}$ & $\begin{array}{l}-0.246 \\
(-0.66)\end{array}$ \\
\hline RENT $_{i t}$ & $\begin{array}{c}-0.0515 \\
(-1.33)\end{array}$ & $\begin{array}{l}-0.106 \\
(-1.42)\end{array}$ & $\begin{array}{c}-0.0859 \\
(-1.59)\end{array}$ \\
\hline $\mathrm{DIM}_{\mathrm{it}}$ & $\begin{array}{c}-0.0055 \\
(-0.50)\end{array}$ & $\begin{array}{c}0.0121 \\
(0.59)\end{array}$ & $\begin{array}{c}0.0013 \\
(0.09)\end{array}$ \\
\hline IDADE $_{\text {it }}$ & $\begin{array}{c}-0.0259 \\
(-1.21)\end{array}$ & $\begin{array}{c}-0.102^{* *} \\
(-3.08)\end{array}$ & $\begin{array}{c}-0.0732^{* *} \\
(-2.74)\end{array}$ \\
\hline $\mathrm{LIQ}_{\mathrm{it}}$ & $\begin{array}{c}-0.6093 * * * \\
(-16.37)\end{array}$ & $\begin{array}{c}-0.0505^{* * *} \\
(-10.45)\end{array}$ & $\begin{array}{c}-0.0560^{* * *} \\
(-13.15)\end{array}$ \\
\hline BFEx $_{\text {it }}$ & $\begin{array}{l}0.103 \\
(0.65)\end{array}$ & $\begin{array}{l}0.452 \\
(1.96)\end{array}$ & $\begin{array}{l}0.396^{*} \\
(2.16)\end{array}$ \\
\hline $\mathrm{LOC}_{\mathrm{i}}$ & $\begin{array}{c}-0.150^{* * *} \\
(-3.93)\end{array}$ & & $\begin{array}{l}-0.127 \\
(-1.82)\end{array}$ \\
\hline Intercept & $\begin{array}{c}1.062^{* * *} \\
(5.69)\end{array}$ & $\begin{array}{l}0.761^{*} \\
(2.11)\end{array}$ & $\begin{array}{c}0.992^{* * *} \\
(3.89)\end{array}$ \\
\hline Sample size & 313 & 313 & 313 \\
\hline $\mathrm{R}^{2}$ & 0.6178 & 0.5141 & 0.5938 \\
\hline Wald chi $^{2}$ & (8.304) & $(7.248)$ & \\
\hline $\mathrm{F}$ & $61.41^{* * *}$ & $23.64^{* * *}$ & $262.09^{* * *}$ \\
\hline
\end{tabular}

Note: *, ** and ${ }^{* * *}$ indicate a statistical significance level of 10,5 , and $1 \%$, respectively.

Source: Prepared by the authors.

The values of the F and Wald tests allow us to state that the determinants explain the dependent variable, at the level of significance of $1 \%$. Considering the values of the LM and Hausman tests, we conclude that the most appropriate model for estimating the relationship between short-term debt and the determinants is the randomeffects model.

Concerning the relationship between short-term debt $\left(\right.$ End $_{\text {ii }}$ ) and its determinants, tangibility (TANG), liquidity (LIQ), and age (IDADE) are negatively related to short-term debt, allowing to validate hypotheses $\mathrm{H}_{3 \mathrm{a}}$, $\mathrm{H}_{6 \mathrm{a}}$, and $\mathrm{H}_{2 \mathrm{a}}$, respectively. These results suggest that firms with a higher level of liquidity and older age depend less on short-term debt. Also, firms with a higher level of tangible assets have a lower level of short-term debt, as they are likely to have fewer short-term debt needs. These results corroborate the principles of the pecking order theory, given that firms with a higher level of tangible assets, older age, and a higher degree of liquidity tend to depend less on short-term debt, probably due to the greater capacity of firms to generate profits to self-finance. Previous studies (Lisbon, 2017; Proença et al., 2014) identified a negative relationship between short-term debt and the determinants of liquidity and tangible assets.

The non-debt tax shield (BFEx) variable has a positive relationship with short-term debt, confirming hypothesis $\mathrm{H}_{7 \mathrm{a}}$. Consequently, firms with more non-debt tax shield have a higher level of short-term debt, contrary to the assumptions of the trade-off theory, which predicts a negative relationship between the two variables. The existence of non-debt tax shield allows firms to obtain tax savings in ways other than debt financing. Consequently, according to the assumptions of the trade-off theory, the level of debt decreases.

To test the relationship between the dependent variable medium and long-term debt, and the independent variables, the results of the LM and Hausman tests (Table 6) allowed us to consider the fixed effects model as the most appropriate model. 
Table 6

Determinants of medium and long-term indebtedness (EndMLP)

\begin{tabular}{|c|c|c|c|}
\hline Independent variables & $\begin{array}{c}(1) \\
\text { Pooled OLS }\end{array}$ & $\begin{array}{c}(2) \\
\text { Fixed effects }\end{array}$ & $\begin{array}{c}\text { (3) } \\
\text { Random effects }\end{array}$ \\
\hline TANG $_{i t}$ & $\begin{array}{c}-0.0744^{*} \\
(-2.20)\end{array}$ & $\begin{array}{c}0.0228 \\
(0.26)\end{array}$ & $\begin{array}{c}-0.0357 \\
(-0.79)\end{array}$ \\
\hline $\mathrm{OpCr}_{\mathrm{it}}$ & $\begin{array}{l}-0.262 \\
(-1.11)\end{array}$ & $\begin{array}{l}0.321 \\
(0.53)\end{array}$ & $\begin{array}{l}-0.149 \\
(-0.51)\end{array}$ \\
\hline $\mathrm{RENT}_{\text {it }}$ & $\begin{array}{c}-0.0099 \\
(-0.31)\end{array}$ & $\begin{array}{c}-0.0793 \\
(-1.05)\end{array}$ & $\begin{array}{c}-0.0282 \\
(-0.66)\end{array}$ \\
\hline $\mathrm{DIM}_{\mathrm{it}}$ & $\begin{array}{c}0.0019 \\
(0.22)\end{array}$ & $\begin{array}{c}-0.0155 \\
(-0.74)\end{array}$ & $\begin{array}{c}0.0036 \\
(0.31)\end{array}$ \\
\hline $\operatorname{IDADE}_{\text {it }}$ & $\begin{array}{c}-0.0023 \\
(-0.13)\end{array}$ & $\begin{array}{c}0.0199 \\
(1.59)\end{array}$ & $\begin{array}{c}0.0152 \\
(0.68)\end{array}$ \\
\hline $\mathrm{LIQ}_{\mathrm{it}}$ & $\begin{array}{c}0.0002 \\
(0.08)\end{array}$ & $\begin{array}{c}0.0089 \\
(1.82)\end{array}$ & $\begin{array}{c}0.0011 \\
(0.30)\end{array}$ \\
\hline BFEx $_{i t}$ & $\begin{array}{c}0.661^{* * *} \\
(4.97)\end{array}$ & $\begin{array}{c}-0.649 * * \\
(-2.76)\end{array}$ & $\begin{array}{l}0.261 \\
(1.66)\end{array}$ \\
\hline $\mathrm{LOC}_{\mathrm{i}}$ & $\begin{array}{c}0.0056 \\
(0.18)\end{array}$ & & $\begin{array}{c}-0.0160 \\
(-0.35)\end{array}$ \\
\hline Intercept & $\begin{array}{c}0.0448 \\
(0.29)\end{array}$ & $\begin{array}{l}0.324 \\
(0.88)\end{array}$ & $\begin{array}{c}-0.0010 \\
(-0.01)\end{array}$ \\
\hline Sample size & 313 & 313 & 313 \\
\hline $\mathrm{R}^{2}$ & 0.0908 & 0.0619 & 0.0641 \\
\hline Wald chi ${ }^{2}$ & (8.304) & (7.248) & \\
\hline $\mathrm{F}$ & $3.79 * * *$ & $2.19^{* *}$ & 4.29 \\
\hline
\end{tabular}

Note: *, ${ }^{* *}$ and ${ }^{* * *}$ indicate a statistical significance level of 10,5 , and $1 \%$, respectively.

Source: Prepared by the authors.

The $\mathrm{H}_{7 \mathrm{~b}}$ hypothesis has been supported by our results, as there is a negative and statistically significant relationship between non-debt tax shields and medium and long-term debt. Therefore, firms with more non-debt tax shields have a lower level of long-term debt. This result confirms the assumption of the trade-off theory, given that a higher level of non-debt tax shields seems to signal the possibility of enjoying tax savings without debt financing.

Table 7

Total indebtedness determinants (EndT)

\begin{tabular}{|c|c|c|c|}
\hline Independent variables & $\begin{array}{c}\text { (1) } \\
\text { Pooled OLS }\end{array}$ & $\begin{array}{c}(2) \\
\text { Fixed effects }\end{array}$ & $\begin{array}{c}\text { (3) } \\
\text { Random effects }\end{array}$ \\
\hline TANG $_{\text {it }}$ & $\begin{array}{c}-0.466^{* * *} \\
(-10.06)\end{array}$ & $\begin{array}{c}-0.423^{* * *} \\
(-3.85)\end{array}$ & $\begin{array}{c}-0.450^{* * *} \\
(-6.61)\end{array}$ \\
\hline $\mathrm{OpCr}_{\mathrm{it}}$ & $\begin{array}{l}0.109 \\
(0.34)\end{array}$ & $\begin{array}{l}-0.777 \\
(-1.04)\end{array}$ & $\begin{array}{l}-0.186 \\
(-0.43)\end{array}$ \\
\hline RENT $_{i t}$ & $\begin{array}{c}-0.0524 \\
(-1.19)\end{array}$ & $\begin{array}{l}-0.126 \\
(-1.35)\end{array}$ & $\begin{array}{l}-0.104 \\
(-1.63)\end{array}$ \\
\hline $\mathrm{DIM}_{\mathrm{it}}$ & $\begin{array}{c}0.0023 \\
(0.19)\end{array}$ & $\begin{array}{c}0.0009 \\
(0.03)\end{array}$ & $\begin{array}{c}0.0005 \\
(0.03)\end{array}$ \\
\hline
\end{tabular}

The remaining variables in the model had statistically non-significant relationships, that is, these variables, besides the non-debt tax shield, do not indicate any influence on medium and long-term indebtedness.

The fixed-effects model, regarding the relationships between total indebtedness and the analyzed determinants, is the most appropriate, considering the results of the LM and Hausman tests (Table 7). 
Table 7

Cont.

\begin{tabular}{|c|c|c|c|}
\hline Independent variables & $\begin{array}{c}\text { (1) } \\
\text { Pooled OLS }\end{array}$ & $\begin{array}{c}(2) \\
\text { Fixed effects }\end{array}$ & $\begin{array}{c}\text { (3) } \\
\text { Random effects }\end{array}$ \\
\hline $\operatorname{IDADE}_{\mathrm{it}}$ & $\begin{array}{c}-0.0243 \\
(-0.99)\end{array}$ & $\begin{array}{c}-0.115^{* *} \\
(-2.74)\end{array}$ & $\begin{array}{c}-0.0596 \\
(-1.86)\end{array}$ \\
\hline $\mathrm{LIQ}_{\mathrm{it}}$ & $\begin{array}{c}-0.0644^{* * *} \\
(-13.32)\end{array}$ & $\begin{array}{c}-0.0367^{* * *} \\
(-6.02)\end{array}$ & $\begin{array}{c}-0.0486^{* * * *} \\
(-9.31)\end{array}$ \\
\hline BFEx $_{\text {it }}$ & $\begin{array}{l}0.808^{* * *} \\
(4.45)\end{array}$ & $\begin{array}{c}-0.0026 \\
(-0.01)\end{array}$ & $\begin{array}{l}0.536^{*} \\
(2.43)\end{array}$ \\
\hline $\mathrm{LOC}_{\mathrm{i}}$ & $\begin{array}{c}-0.177^{* * *} \\
(-4.05)\end{array}$ & & $\begin{array}{l}-0.175^{*} \\
(-2.29)\end{array}$ \\
\hline Intercept & $\begin{array}{c}0.986^{* * * *} \\
(4.63)\end{array}$ & $\begin{array}{l}1.021^{*} \\
(2.24)\end{array}$ & $\begin{array}{c}1.056^{* * *} \\
(3.54)\end{array}$ \\
\hline Sample size & 313 & 313 & 313 \\
\hline $\mathrm{R}^{2}$ & 0.5723 & 0.3953 & 0.5507 \\
\hline Wald chi $^{2}$ & $(8.304)$ & $(7.248)$ & \\
\hline $\mathrm{F}$ & $50.85^{* * *}$ & $9.67^{* * *}$ & $159.51^{* * *}$ \\
\hline
\end{tabular}

Note: *, ** and ${ }^{* * *}$ indicate a statistical significance level of 10,5 , and $1 \%$, respectively.

Source: Prepared by the authors.

The relationships of the relevant determinants in the fixed effects model, such as liquidity (LIQ) and age (IDADE), are negatively related to total indebtedness (EndT) and are statistically significant at the significance levels of $1 \%$ and $5 \%$, respectively. Considering the relationship presented by each of the variables with the total indebtedness, the hypotheses $\mathrm{H}_{6 c}$ and $\mathrm{H}_{3 \mathrm{c}}$ respectively, are supported by our results. They indicate that a higher level of liquidity and older age imply less total debt. The tangibility variable is statistically significant at $1 \%$ of significance, but it does not support the $\mathrm{H}_{1 \mathrm{c}}$ hypothesis in terms of the relationship proposed in this research. Previously, there was also a negative relationship between the variable tangibility and short-term debt.

Therefore, SMEs with a higher level of tangible assets have lower levels of short-term debt and total debt. These results corroborate that the level of the total indebtedness of SMEs in Cabinda is close to the level of short-term indebtedness, so the relationships between the determinants and the ratios of total indebtedness and short-term indebtedness are similar. These results also demonstrate the importance of analyzing short-term and long-term debt ratios. Consequently, the total debt ratio was decomposed to further understand the determinants of the capital structure in the context of SMEs.

Table 8 shows a summary of the determinants of the three most appropriate models in this study, taking into account the LM and Hausman tests, for short-term debt, medium and long-term debt, and total SME indebtedness in Cabinda (Table 8).

Table 8

Summary of determinants of short and long-term and total indebtedness

\begin{tabular}{|c|c|c|c|}
\hline Independent variables & $\begin{array}{c}(\text { EndCP) } \\
\text { Random effects }\end{array}$ & $\begin{array}{l}\text { (EndMLP) } \\
\text { Fixed effects }\end{array}$ & $\begin{array}{c}(\text { EndT }) \\
\text { Fixed effects }\end{array}$ \\
\hline TANG $_{\text {it }}$ & $\begin{array}{c}-0.427^{* * *} \\
(-7.32)\end{array}$ & $\begin{array}{c}0.0228 \\
(0.26)\end{array}$ & $\begin{array}{c}-0.423^{* * *} \\
(-3.85)\end{array}$ \\
\hline $\mathrm{OpCr}_{\mathrm{it}}$ & $\begin{array}{l}-0.246 \\
(-0.66)\end{array}$ & $\begin{array}{l}0.321 \\
(0.53)\end{array}$ & $\begin{array}{l}-0.777 \\
(-1.04)\end{array}$ \\
\hline $\mathrm{RENT}_{\mathrm{it}}$ & $\begin{array}{c}-0.0859 \\
(-1.59)\end{array}$ & $\begin{array}{c}-0.0793 \\
(-1.05)\end{array}$ & $\begin{array}{l}-0.126 \\
(-1.35)\end{array}$ \\
\hline $\mathrm{DIM}_{\mathrm{it}}$ & $\begin{array}{c}0.0013 \\
(0.09)\end{array}$ & $\begin{array}{c}0.0009 \\
(0.03)\end{array}$ & $\begin{array}{c}0.0009 \\
(0.03)\end{array}$ \\
\hline $\mathrm{IDADE}_{\mathrm{it}}$ & $\begin{array}{c}-0.0732^{* *} \\
(-2.74)\end{array}$ & $\begin{array}{c}-0.115^{* *} \\
(-2.74)\end{array}$ & $\begin{array}{c}-0.115^{* *} \\
(-2.74)\end{array}$ \\
\hline
\end{tabular}


Table 8

Cont.

\begin{tabular}{|c|c|c|c|}
\hline Independent variables & $\begin{array}{c}(\text { EndCP) } \\
\text { Random effects }\end{array}$ & $\begin{array}{l}\text { (EndMLP) } \\
\text { Fixed effects }\end{array}$ & $\begin{array}{c}(\text { EndT) } \\
\text { Fixed effects }\end{array}$ \\
\hline $\mathrm{LIQ}_{\mathrm{it}}$ & $\begin{array}{c}-0.0560^{* * *} \\
(-13.15)\end{array}$ & $\begin{array}{c}-0.0367^{* * *} \\
(-6.02)\end{array}$ & $\begin{array}{c}-0.0367^{* * *} \\
(-6.02)\end{array}$ \\
\hline BFEx $_{\text {it }}$ & $\begin{array}{l}0.396^{*} \\
(2.16)\end{array}$ & $\begin{array}{c}-0.0026 \\
(-0.01)\end{array}$ & $\begin{array}{c}-0.0026 \\
(-0.01)\end{array}$ \\
\hline $\operatorname{LOC}_{i}$ & $\begin{array}{l}-0.127 \\
(-1.82) \\
\end{array}$ & & \\
\hline Intercept & $\begin{array}{c}0.992 * * * \\
(3.89) \\
\end{array}$ & $\begin{array}{c}1.021^{*} \\
(2.24)\end{array}$ & $\begin{array}{c}1.021^{*} \\
(2.24) \\
\end{array}$ \\
\hline Sample size & 313 & 313 & 313 \\
\hline $\mathrm{R}^{2}$ & 0.5938 & 0.3953 & 0.3953 \\
\hline Wald chi ${ }^{2}$ & & (7.248) & (7.248) \\
\hline $\mathrm{F}$ & $262.09 * * *$ & $9.67^{* * *}$ & $9.67^{* * *}$ \\
\hline
\end{tabular}

Note: *,** and *** indicate a statistical significance level of 10,5 , and $1 \%$, respectively.

Source: Prepared by the authors.

The negative and statistically significant relationship between the tangibility of assets and the levels of shortterm debt suggests that SMEs tend to reduce short-term debt when they have a higher level of tangible assets, which may be a consequence of the larger size of the firm and, therefore, less need for short-term debt financing. These results corroborate previous studies (Palacín-Sánchez et al., 2013; Sardo \& Serrasqueiro, 2017).

The relationships obtained in this study were also identified in several previous empirical studies, such as Vo (2017), which, in the context of Vietnam, found a negative and significant relationship between tangibility and shortterm debt and a positive and significant relationship with long-term debt.

Benkraiem and Gurau (2013), in their study on French SMEs, found evidence that tangibility is negatively related to short-term indebtedness and total indebtedness, but positively to long-term indebtedness.

The negative relationship between age and short-term and total debts found in this study suggests that the older SMEs are suggests that the older SMEs are, the less they resort to borrowed capital in the form of short-term debt. These results corroborate the principles of the pecking order theory, according to which older firms are more capable of self-financing, becoming less dependent on debt financing. Several authors (Palacín-Sánchez et al., 2013; Matias \& Serrasqueiro, 2017; Mc Namara et al. 2017) identified a negative and significant relationship between the age of SMEs and short-term and long-term debt.

Evidence of the negative relationship found in this study between liquidity and short-term and total debt indicates that the SMEs under analysis that has a higher level of liquidity seems to reduce the debt financing, corroborating the assumptions of the pecking order theory. In the context of Portuguese SMEs, Proença et al. (2014) identified a negative and statistically significant relationship between liquidity and short-term debt and total debt and a positive and statistically significant relationship between liquidity and long-term debt.

The empirical evidence obtained in this study on the positive relationship between non-debt tax shield and short-term debt indicates that the owners/managers of the SMEs analyzed here do not reduce the use of short-term third-party capital in the presence of other non-debt tax shield. This result contradicts the principles of the trade-off theory, which predicts a negative relationship between that determinant and the debt. On the other hand, the negative and statistically significant relationship between non-debt tax shield and medium and long-term debt indicates that a higher level of nondebt tax shield has a negative impact on medium and long-term debt. This result confirms the assumptions of the trade-off theory.

Sardo and Serrasqueiro (2017) analyzed the impact of non-debt tax shield on the level of short-term and long-term indebtedness of small and medium-sized Portuguese firms. These authors identified a positive and significant relationship at $1 \%$ of significance between the non-debt tax shield and short-term debt for the group of small firms and the group of medium-sized firms, and a positive and significant relation at $1 \%$ of significance was verified for short-term debt and longterm debt, respectively. 


\section{CONCLUSION, LIMITATIONS, AND FUTURE RESEARCH PERSPECTIVES}

To develop this research, we conducted a literature review of the various empirical studies in different contexts on the determinants of capital structure decisions, focusing on the specific factors of the firm. Our objective was to analyze the determinants of the capital structure decisions of SMEs in the province of Cabinda, in Angola.

Our results demonstrantes that SMEs in Cabinda depend mainly on short-term debt to finance themselves, while the average level of medium and long-term debt is very low. Thus, it is important to break down the total debt ratio into short, medium, and long-term debt ratios in the analysis of SMEs' capital structure decisions.

Our results also show that the determinants that negatively influence short-term debt are the tangibility of the asset, the age of the firm, and liquidity, while the nondebt tax shield are positively related to it. For medium and long-term debt, only non-debt tax shield have statistical significance as a determinant of capital structure, with a negative relationship. Finally, for total indebtedness, the significant determinants are the tangibility of the asset, the age of the firm, and the negatively related liquidity. These relationships are in line with the relationships identified for short-term indebtedness, thus highlighting the importance of decomposing the total indebtedness ratio into the short, medium, and long-term indebtedness ratio.

The negative and statistically significant relationship between the tangibility and the level of short-term debt corroborates the principles of the pecking order theory, which assumes that the higher the level of tangible assets of SMEs, the less the need to resort to short-term debt. Besides, SMEs located in Cabinda have a very low medium and long-term debt level, which probably explains the absence of statistically significant relationships with the capital structure determinants considered in this study. The relationship between the tangibility of the asset and total indebtedness is negative, similar to the relationship identified between this determinant and short-term indebtedness. Thus, the patterns of financing based on total indebtedness seem close to those of short-term indebtedness, probably due to the low level of medium and long-term indebtedness of SMEs in Cabinda.
Based on the evidence obtained in this study, we conclude that the older the firm, Cabinda's SMEs resort less on short-term and total indebtedness, as suggested by the pecking order theory. Our empirical results also showed that the geographic location of SMEs in Cabinda, considering the asymmetries in the economic development of the different municipalities in the province, is not statistically significant for the three models that we analyzed. This result can be explained by the fact that these SMEs are in the same province, so the location of the municipalities does not seem to impact the level of indebtedness of SMEs in Cabinda.

This study has several implications: (i) for managers of SMEs located in developing countries and developed countries, it highlights the importance of disclosing reliable information about the firm to access credit on favorable terms; (ii) for academia, we suggest to qualitative research in the context of SMEs to deepen the understanding of capital structure decisions; (iii) for politicians, the results of this study suggest the need for measures to support SMEs in the preparation and dissemination of financial information to reduce the problems of information asymmetry and access credit on more favorable terms.

We also highlight some of this study's main limitations: data had to be surveyed manually due to the lack of databases with financial information about SMEs in Cabinda; some SMEs were unavailable to provide financial information to researchers because some of them considered the requested information confidential; the sample size was affected (reduced), considering the impossibility for SMEs to provide complete data for the period under analysis in this study.

Finally, as directions for future research, we suggest the expansion of the sample and the period of analysis; studies by sectors of economic activity; consideration of macroeconomic variables and variables representative of the characteristics of the owner/manager as determinants of the capital structure decisions of SMEs in Angola. Additionally, we suggest comparative studies on the capital structure decisions of SMEs located in different countries in Sub-Saharan Africa. 


\section{REFERENCES}

Adair, P., \& Adaskou, M. (2015). Trade-off-theory vs. pecking order theory and the determinants of corporate leverage: evidence from a panel data analysis upon French SMEs (20022010). Cogent Economics \& Finance, 3(1), 1-12.

Ahmad, R., \& Etudaiye-Muhtar, O. F. (2017). Dynamic model of optimal capital structure: Evidence from Nigerian listed firms Global Business Review, 18(3), 590-604.

Al-Najjar, B., \& Al-Najjar, D. (2017). The impact of external financing on firm value and a corporate governance index: SME evidence. Journal of Small Business and Enterprise Development, 24(2), 4.

Baker, M., \& Wurgler, J. (2002). Market timing and capital structure. The Journal of Finance, 57(1), 1-32.

Benkraiem, R., \& Gurau, C. (2013). How do corporate characteristics affect capital structure decisions of French SMEs? International Journal of Entrepreneurial Behaviour \& Research, 19(2), 149-164.

Bevan, A., \& Danbolt, J. (2002). Capital structure and its determinants in the United Kingdom - a decompositional analysis. Applied Financial Economics, 12(3), 159-170.

Bhaduri, S. N. (2002). Determinants of capital structure choice: a study of the Indian corporate sector. Applied Financial Economics, 12(9), 655-665.

Bhaird, M. C., \& Lucey, B. (2014). Culture's influences: An investigation of inter-country differences in capital structure. Borsa Istanbul Review, 14(1), 1-9.

Burgstaller, J., \& Wagner, E. (2015). How do family ownership and founder management affect capital structure decisions and adjustment of SMEs? The Journal of Risk Finance, 16(1), 73-101.

Buvanendra, S., Sridharan, P., \& Thiyagarajan, S. (2017). Firm characteristics, corporate governance and capital structure adjustments: A comparative study of listed firms in Sri Lanka and India. IIMB Management Review, 29(4), 245-258.

Cassar, G., \& Holmes, S. (2003). Capital structure and financing of SMEs: Australian evidence. Accounting and Finance, 43(2), 123-147.

Chakraborty, I. (2010). Capital structure in an emerging stock market-case of India. Research in International Business and Finance, 24(3), 295-314.

Dasilas, A., \& Papasyriopoulos, N. (2015). Corporate governance, credit ratings and the capital structure of Greek SME and large listed firms. Small Business Economics, 45, 215-244.

De Jong, A., Kabir, R., \& Nguyen, T. T. (2008). Capital structure around the world: The roles of firm- and country-specific determinants. Journal of Banking and Finance, 32(9), 19541969.

Degryse, H., de Goeij, P., \& Kappert, P. (2012). The impact of firm and industry characteristics on small firms' capital structure. Small Business Economics, 38, 431-447.

Durand, D. (1952). Costs of debt and equity funds for business: trends and problems of measurement. In UniversitiesNational Bureau. Conference on Research in Business Finance (pp. 215-262). Cambridge, MA: NBER.
Dwyer, B., \& Kotey, B. (2015). Financing SME Growth : The role of the national stock exchange of Australia and business advisors. Australian Accounting Review, 25(73), 114-123.

Erdogan, A. I. (2018). Factors affecting SME access to bank financing: an interview study with Turkish bankers. Small Enterprise Research, 25(1), 23-35.

Ezirim, C. B., Ezirim, U. I., \& Momodu, A. A. (2017). Capital structure and firm value: Empirical evidence from Nigeria. International Journal of Business, Accounting, and Finance, 11(1), 68-89.

Fama, E. F., \& French, K. R. (2002). Testing trade-off and pecking order predictions about dividends and debt. The Review of Financial Studies, 15(1), 1-33.

Fowowe, B. (2017). Access to finance and firm performance: Evidence from African countries. Review of Development Finance, 7(1), 6-17.

Frank, M., \& Goyal, V. (2003). Testing the pecking order theory of capital structure. Journal of Financial Economics, 67(2), 217-248.

Hall, G. C., Hutchinson, P. J., \& Michaelas, N. (2004). Determinants of the capital structures of European SMEs. Journal of Business Finance \& Accounting, 31(5-6).

Haro-de-rosario, A., Caba-Pérez, M. del C., \& Cazorla-papis, L. (2015). The impact of venture capital on investee firms: evidence from Spain. Review of Managerial Science, 10, 577600.

Hendrawan, B. (2012). The small medium-free trade zone that able to acquire debt. Procedia Social and Behavioral Sciences, 4, 76-85.

Heyman, D., Deloof, M., \& Ooghe, H. (2008). The financial structure of private held Belgian firms. Small Business Economics, 30, 301-313.

Holmes, S., \& Kent, P.(1991). An empirical analysis of the financial structure of small and large Australian manufacturing enterprises. Journal Small Business Finance, 1, 141-154.

Jensen, M. C. (1986). Agency costs of free cash flow, corporate finance, and takeovers. The American Economic Review, 76(2), 323-329.

Jensen, M. C., \& Meckling, W. H. (1976). Theory of the firm: Managerial behavior, agency costs and ownership structure. Journal of Financial Economics, 3(4), 305-360.

Jiraporn, P., \& Gleason, K. C. (2007). Capital structure, shareholder rights, and corporate governance. Journal of Financial Research, 30, 21-33.

Kraus, A., \& Litzenberger, R. (1973). A state-preference model of optimal financial leverage. Journal of Finance, 28(4), 911-22.

Kontuš, E., \& Mihanović, D. (2019). Management of liquidity and liquidassets in small and medium-sized enterprises. Economic Research-Ekonomska Istraživanja, 32(1), 3247-3265

Lee, N., Sameen, H., \& Cowling, M. (2015). Access to finance for innovative SMEs since the financial crisis. Research Policy, 44(2), 370-380. 
Li, L., \& Islam, S. Z. (2019). Firm and industry specific determinants of capital structure: Evidence from the Australian market. International Review of Economics and Finance, 59, 425-437.

Lisboa, I. (2017). Capital structure of exporter SMEs during the financial crisis: Evidence from Portugal. European Journal of Management Studies, 22(1), 25-49.

Mac an Bhaird, C., \& Lucey, B. (2010). Determinants of capital structure in Irish SMEs. Small Business Economics, 35, 357375.

Maes, E., Dewaelheyns, N., Fuss, C., \& Van Hulle, C. (2019). The impact of exporting on financial debt choices of SMEs. Journal of Business Research, 102, 56-73.

Mateeva, M., Poutziouris, P., \& Ivanov, K. (2013). On the determinants of SME capital structure of Eastern and Central Europe: A dynamic panel analysis. Research in International Business and Finance, 27(1), 28-51.

Matemilola, B. T., Bany-Ariffin, A. N., Azman-Saini, W. N. W., \& Nassir, A. M. (2018). Does top managers' experience affect firms' capital structure? Research in International Business and Finance, 45, 488-498.

Matias, F., Baptista, C., \& Salsa, L. (2015). Estrutura do capital das PME da indústria transformadora portuguesa: uma análise com dados em painel. Tourism \& Management Studies, 11(2), 120-129.

Matias, F., \& Serrasqueiro, Z. (2017). Are there reliable determinant factors of capital structure decisions? Empirical study of SMEs in different regions of Portugal. Research in International Business and Finance, 40, 19-33.

Mc Namara, A., Murro, P., \& O’Donohoe, S. (2017). Countries lending infrastructure and capital structure determination: The case of European SMEs. Journal of Corporate Finance, 43, 122-138.

Michaelas, N., Chittenden, F., \& Poutziouris, P. (1999). Financial policy and capital structure choice in UK SMEs: Empirical evidence from firm panel data, Small Business Economics, 12, 113-130.

Modigliani, F., \& Miller, M. H. (1963). Corporate income taxes and the cost of capital: A correction. The American Economic Review, 53(3), 433-443.

Modigliani, F., \& Miller, M. H. (1958). The cost of capital, corporation finance and the theory of investment. The American Economic Review, 48(3), 261-297.

Myers, S. C. (1984). The capital structure puzzle. The Journal of Finance, 39(4), 575-592.

Myers, S. C., \& Majluf, N. S. (1984). Corporate financing and investment decisions when firms have information the investors do not have. Journal of Financial Economics, 13(2), 187-221.

Nunkoo, P. K., \& Boateng, A. (2010). The empirical determinants of target capital structure and adjustment to long-run target: Evidence from Canadian firms. Applied Economics Letters, 17(10), 983-990.

Öhman, P., \& Yazdanfar, D. (2017). Short- and long-term debt determinants in Swedish SMEs. Review of Accounting and Finance, 16(1), 106-124.
Palacín-Sánchez, M. J., Ramírez-Herrera, L. M., \& di Pietro, F. (2013). Capital structure of SMEs in Spanish regions. Small Business Economics, 41, 503-519.

Peñaloza, V., \& Figueiredo, F. de C. (2011). Fatores que influenciam a estrutura de capital em micro e pequenas empresas. Revista Pretexto, 12(1), 9-28.

Proença, P., Laureano, R., \& Laureano, L. (2014). Determinants of capital structure and the 2008 financial crisis: Evidence from Portuguese SMEs. Social Behavioral Sciences, 150, 182-191.

Rao, P., \& Kumar, S. (2018). Reflection of owner's attributes in financing decisions of SMEs, Small Enterprise Research, 25(1), 52-68.

Rao, P., Kumar, S., \& Madhavan, V. (2019). A study on factors driving the capital structure decisions of small and medium enterprises (SMEs) in India. IIMB Management Review, 31(1), 37-50.

Russo, P. F., \& Rossi, P. (2001). Credit constraints in Italian industrial districts. Applied Economics, 33(11), 1469-1477.

Santos, A., Ribeiro, N., Silva, W., \& Melo, A. (2016). Determinantes da estrutura de capital de pequenas empresas da região metropolitana de Belo Horizonte. Revista Universo Contábil, 55(31), 80-95.

Sardo, F., \& Serrasqueiro, Z. (2017). Does dynamic trade-off theory explain Portuguese SME capital structure decisions? Journal of Small Business and Enterprise Development, 24(3), 485-502.

Scherr, F. C., \& Hulburt, H. M. (2001). The debt maturity structure of small firms. Financial Management, 30, 85-111.

Serrasqueiro, Z., \& Nunes, P. M. (2012). Is age a determinant of smes' financing decisions? Empirical evidence using panel data models. Entrepreneurship: Theory and Practice, 36(4), 1-28.

Takele, Y., \& Beshir, D. (2017). Firm-specific determinants of insurance firms' capital structure in Ethiopia. In A. Heshmati (Ed.). Studies on economic development and growth in selected African countries (pp. 155-175). London: Springer.

Vatavu, S. (2012). Trade-off versus Pecking Order Theory in listed firms around the world. Annals of the University of Petroşani, Economics, 12(2), 285-292.

Vieira, E. S., \& Novo, A. J. (2010). A estrutura de capital das PME: evidência no mercado português. Estudos do ISCA, 4(2), 2-16.

Vo, X. V. (2017). Determinants of capital structure in emerging markets: Evidence from Vietnam. Research in International Business and Finance, 40, 105-113.

Wong, A., Holmes, S., \& Schaper, M. T. (2018). How do small business owners actually make their financial decisions? Understanding SME financial behaviour using a case-based approach. Small Enterprise Research, 25(1), 36-51.

Yazdanfar, D., \& Öhman, P. (2016). The impact of trade credit use on firm profitability: empirical evidence from Sweden. Journal of Advances in Management Research, 13(2), 116-129.

Yildirim, R., Masih, M., \& Bacha, O. I. (2018). Determinants of capital structure: evidence from Shariah compliant and noncompliant firms. Pacific Basin Finance Journal, 51, 198-219.

Zhao, T., \& Jones-Evans, D. (2016). SMEs, banks and the spatial differentiation of access to finance. Journal of Economic Geography, 17(4) 791-824. 